\title{
Notes on Two Introduced Populations of the Italian Wall Lizard (Podarcis siculus) on Staten Island, New York
}

\author{
Robert W. Mendyk ${ }^{1,2}$ and John Adragna ${ }^{3}$ \\ ${ }^{1}$ Department of Herpetology, Smithsonian National Zoological Park, 3001 Connecticut Ave NW, Washington, D.C. 20008, USA (MendykR@si.edu) \\ ${ }^{2}$ Department of Herpetology, Jacksonville Zoo and Gardens, 370 Zoo Parkway, Jacksonville, FL 32218, USA \\ ${ }^{3} 605$ Greeley Avenue, Staten Island, NY 10306, USA
}

$\mathrm{T}_{\mathrm{s}}^{\mathrm{h}}$ he Italian Wall Lizard (Podarcis siculus) has been introduced to temperate regions of the United States on at least seven occasions. Although a colony that once persisted in Philadelphia, Pennsylvania (Kauffeld 1931) is now believed to have been extirpated (Burke and Deichsel 2008), established breeding populations of $P$. siculus currently exist in New York (Mendyk 2007, Burke and Deichsel 2008), Connecticut (Donihue et al. 2014), New Jersey (Burke 2010), Kansas (Gubanyi 1999, Taggart 2004, Collins et al. 2010), and California (Deichsel et al. 2010).

Italian Wall Lizards were introduced to Long Island, New York around 1967 (Gossweiler 1975, Alvey 1993, Burke and Deichsel 2008), when a group of lizards were released, or escaped from a pet store in a suburban neighborhood of Nassau County. The lizards spread quickly throughout the surrounding area, dispersing through residential neighborhoods, municipal yards, and along railways of the Long Island Railroad (Alvey 1993, Mendyk 2007, Burke and Deichsel 2008). Since their introduction, more than 20 satellite populations (Burke and Deichsel 2008, Burk et al. 2010) have arisen throughout urban and suburban environments of Nassau and Suffolk Counties of Long Island, as well as the New York City boroughs of Queens (Queens County), Brooklyn (Kings County), Manhattan (New York County), and the Bronx (Bronx County) through a combination of natural and human-assisted dispersal including the intentional release of animals in new locations and accidental transport within landscaping material (Alvey 1993, Mendyk 2007, Burke and Deichsel 2008). To date, the only New York City borough without a documented P. siculus population has been Staten Island (Richmond County).

In 2010, K. Geritano (pers. comm.) informed JA that a population of lizards was present in the Great Kill and Historic Richmond Town area of central Staten Island. Searches of the

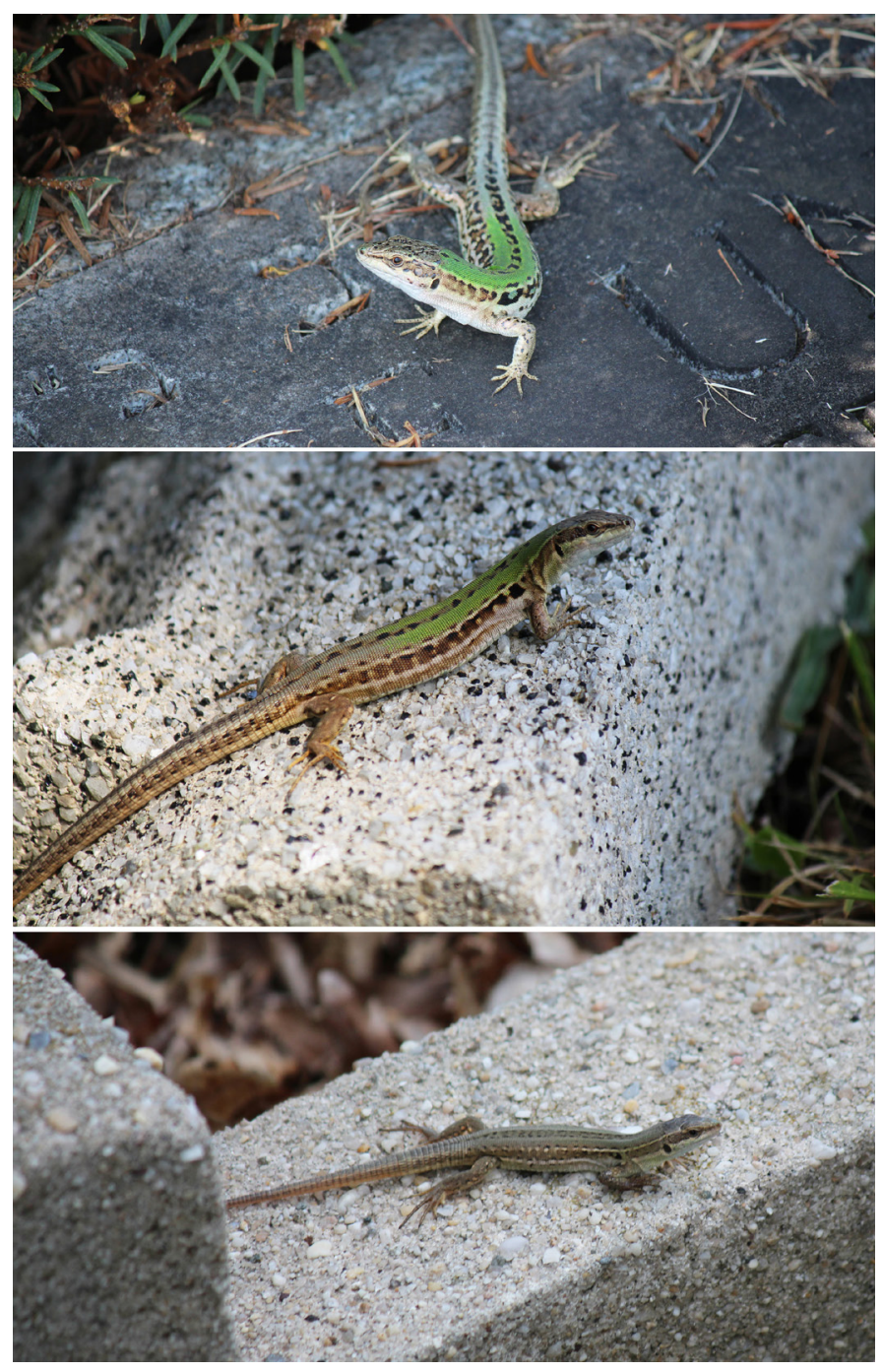

Fig. 1. Italian Wall Lizards (Podarcis siculus) at Mount Richmond Cemetery, Staten Island, New York (2 September 2014): Adult male (top), adult female (center), and juvenile (bottom). Photographs by the senior author. 
area confirmed the presence of $P$. siculus at a private residence on Tanglewood Drive as well as at the nearby United Hebrew Cemetery. Further searches carried out by RWM in the summer of 2014 noted a large population of lizards at the United Hebrew Cemetery as well as the adjacent Mount Richmond Cemetery, where the lizards utilize tombstones and other stone and concrete structures for basking and refuges (Fig. 1). R. Powell confirmed the identity of the lizards from these photographs. A photographic voucher has been accessioned in the Milwaukee Public Museum (MPM P771).

Informal surveys conducted at Mount Richmond Cemetery generated estimates of population densities in excess of one lizard per $\mathrm{m}^{2}$ in some partially shaded areas with abundant tombstones. Sightings of P. siculus also have been reported in nearby residential areas along Greaves Avenue and Center Street, and at Kingfisher Park (J. Catalano, pers. comm.; Anonymous, pers. comm.), leading to an estimated range of at least $1.2 \mathrm{~km}^{2}$. The exact origin and year of introduction remain unclear. Former residents of the area have reported seeing them as early as 2007 (J. Catalano, pers. comm.), although the population is probably much older. A large (ca. $220 \mathrm{ha}$ ), undeveloped, and partially wooded property located directly across Arthur Kill Road from the United Hebrew Cemetery appears to offer habitat similar to that used by $P$. siculus in other areas of New York, and may represent an area through which lizards can spread and substantially increase their range within the interior of the island.

A second, smaller population of P. siculus occurs in the residential neighborhood of New Dorp Beach in southeastern Staten Island, approximately $3 \mathrm{~km}$ east of the aforementioned population. This satellite population originated in the summer of 2012 from six individuals collected from the interior of the island and released at a private residence on Manila Place (Anonymous, pers. comm.). In October 2012, the neighborhood was severely flooded with more than two meters of seawater as a result of Hurricane Sandy. Floodwaters did not completely recede for several days. Some individuals managed to survive the flooding that affected much of the southeastern coastline of the island; adult $P$. siculus were observed near the original point of release the following spring and hatchlings appeared later that summer. Given the extent of the flooding and the species' largely terrestrial habits, how or where these survivors sought refuge is unclear, particularly as the lizards probably had become inactive given the cool daytime temperatures $\left(<10^{\circ} \mathrm{C}\right)$ experienced during the week leading up to the storm.

Populations of P. siculus on Staten Island do not pose any immediate threat to indigenous lizards since no lizards are native to the island (a small population of Sceloporus undulatus presently exists, but these were introduced by Staten Island Zoo reptile curator Carl Kauffeld in 1942 [Kauffeld, 1948]). However, these populations could serve as reservoirs for future introductions to new areas on the mainland where they could affect indigenous species and where they might affect native invertebrates.

\section{Acknowledgements}

We thank J. Catalano, K. Geritano, and an anonymous individual for sharing sightings, observations, and historical details, and the Smithsonian National Zoological Park for its continued support.

\section{Literature Cited}

Alvey, R. 1993. The Garden City Wall Lizard History and Population. Report to the Garden City Environmental Advisory Board, Garden City, New York.

Burke, R.L. 2010. Geographic distribution. Podarcis sicula campestris (Italian Wall Lizard). Herpetological Review 41:514.

Burke, R.L. and G. Deichsel. 2008. Lacertid lizards introduced into North America: History and future, pp. 347-353. In: J.C. Mitchell, R.E.J. Brown, and B. Bartholomew (eds.), Urban Herpetology. Herpetological Conservation, Volume 3. Society for the Study of Amphibians and Reptiles, Salt Lake City, Utah.

Burke, R.L., D. Allen, B. Cacace, R. Cicchetti, E. Cohen, and R. DeCandido. 2010. Podarcis siculus (Italian Wall Lizard). Predation. Herpetological Review 41:85-86.

Collins, J.T., S.L. Collins, and T.W. Taggart. 2010. Amphibians, Reptiles, and Turtles in Kansas. Eagle Mountain Publishing LC, Eagle Mountain, Utah.

Deichsel, G., G. Nafis, and J. Hakim. 2010. Geographic distribution. Podarcis siculus (Italian Wall Lizard). Herpetological Review 41:513-514.

Donihue, C.M., M.R. Lambert, and G.J. Watkins-Colwell. 2014. Geographic distribution. Podarcis sicula (Italian Wall Lizard). Herpetological Review 45:661662.

Gossweiler, W.A. 1975. European lizards established on Long Island. Copeia 1975:584-585.

Gubanyi, J.E. 1999. Update on Lacerta in Topeka, Kansas. Kansas Herpetological Society News 118:13-14.

Kauffeld, C.F. 1931. Lacerta mellisellensis fiumana at Philadelphia. Copeia 1931:163-164.

Kauffeld, C.F. 1948. Introduced fence lizards on Staten Island, New York. Copeia 1948:301

Mendyk, R.W. 2007. An expanding population of Italian Wall Lizards in New York: Podarcis sicula campestris. Reptilia 55:65-71.

Taggart, T.W. 2004. Geographic distribution. Podarcis sicula. Kansas. Journal of Kansas Herpetology 10:10. 